\title{
Spatial dysfunction in post-tsunami Baan Lion: Taking the Moken beyond vulnerability and tradition
}

\author{
Duncan McDuie-Ra a , Daniel Robinson ${ }^{\mathrm{b}, *}$, Jaruwan Kaewmahanin ${ }^{\mathrm{b}}$

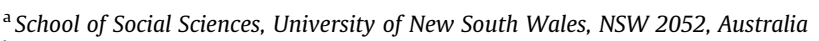 \\ ${ }^{\mathrm{b}}$ Institute of Environmental Studies, University of New South Wales, NSW 2052, Australia
}

\section{A R T I C L E I N F O}

\section{Article history:}

Received 12 December 2012

Received in revised form 9 April 2013

Available online 20 May 2013

\section{Keywords:}

Moken

Thailand

Place-making

Post-tsunami reconstruction

\begin{abstract}
A B S T R A C T
This article focuses on the perpetuation of discourses of vulnerability and tradition for Moken people living on the Andaman Coast in Thailand. These discourses limit opportunities to see Moken agency and changes to contemporary livelihoods/lifestyles. This is depicted through the lens of the post-tsunami reconstructed village of Baan Lion on Koh Phra Thong island. We highlight that inappropriate donor reconstruction has led to spatial dysfunction for the local community (largely Moken). The village provides limited opportunity for place-making, connections to employment and trade, and some of the social benefits offered in other nearby local settings. While donors may have 'built back safer', we argue that they have not 'built back better', as their perception of local needs, livelihoods and lifestyle has not accounted for changes to contemporary Moken life that have occurred prior to and after the 2004 tsunami. The results are a largely depopulated and dysfunctional space whereby NGO and tourism activities are now trying to build a new sense of community and provide some opportunities to retain at least some of the transient population of Baan Lion.
\end{abstract}

(ㄷ) 2013 Elsevier Ltd. All rights reserved.

\section{Introduction}

On the island of Koh Phra Thong off Thailand's Andaman Coast lies the village of Baan Lion. Built following the devastation of the 2004 Asian Tsunami, Baan Lion has approximately 100 houses. Near identical aside from some minor variations between the houses built in stage one (completed in 2008) and stage two (completed in 2010), the white two-storey houses sit in neat rows along a grid pattern. The Lions Club International Foundation (LCIF) funded Baan Lion; hence the name. The majority of houses were given free to the former residents of Pak Chok, a village completely destroyed in the tsunami, of which the majority of former residents are members of the Moken ethnic minority. Most affected families from Pak Chok were able to get a brand new house without difficulty, even if they had no evidence of title in the old village. This in itself is a major boon for villagers as the onus of proving title can be difficult in resettlement sites in other locations. At first glance the large orderly village appears to reflect the LCIF pledge to 're-build lives' following the tsunami. Yet by early 2012 the village was almost empty. Whole sections of the village contained run-down houses that had been abandoned, others are used occasionally, and others have never been occupied. Of the houses that

\footnotetext{
* Corresponding author.

E-mail addresses: d.mcduie@unsw.edu.au (D. McDuie-Ra),d.robinson@unsw. edu.au (D. Robinson), Jaruwan.ning@gmail.com (J. Kaewmahanin).
}

are occupied, the residents are different to those intended by the donors; especially when it comes to the Moken community from Pak Chok. This article is concerned with the simple question; why is Baan Lion almost empty? We focus on the Moken community - the most conspicuous absentees from the village.

In addressing this question we make a two-fold argument. First, Baan Lion demonstrates two related development failures: (i) spatial dysfunction and (ii) limited possibilities for place-making. Second, these failures are informed by a partial understanding of the Moken community that focuses on vulnerability over agency and tradition over rapidly changing lifestyles. As such Baan Lion is more than another embodiment of divergent worldviews in a dysfunctional development project. A study of the village and the lives of its intended inhabitants provides insights into the complexities of contemporary Moken life alongside the persistence of dated understandings of the same community.

Research for this article was carried out in Moken inhabited areas of the Thai Andaman Coast in early 2012 and again in early 2013. Interviews with members of Moken communities and other village residents (Thai and Burmese) were carried out in villages on Koh Phra Thong including Baan Lion, Tah Pae Yoi and Thung Daap. A visit was also made to Moken communities on Koh Surin, a national park further away from the coast where there is a Moken settlement, to verify some of the interview comments made elsewhere. Interviews were also undertaken at Thep Parat on the mainland, built by Caritas and a Catholic Mission after the tsunami, and 
Chaipattana, established by the Chaipattana Foundation (the King's foundation) on the mainland shortly after the tsunami. Interviews were largely informal and took place with individuals and with small groups. We also spoke to members of local NGOs based in the regional hub of Kuraburi and on Koh Phra Thong to triangulate findings. It is difficult to present a total number of interviews conducted for this research (approximately 40). The style of interviewing undertaken in the project varied dramatically in the different sites and among different respondents. Some interviews were brief conversations while others lasted for several hours. Some took place with individuals while others were conducted in groups. Some were one-off while others involved several conversations over a number of days, often among the same individuals in different sites.

As the two primary researchers are neither Thai nor Moken, we were treated as distant outsiders, removed from contentious local issues. This had advantages when discussing certain issues, especially related to donor and government interventions following the tsunami. Yet our foreignness also had disadvantages, especially when discussing Moken lives and livelihoods. Since the end of the tsunami researchers, government officials, NGO staff, and donor representatives have visited Moken communities frequently. Given their small population and unprecedented interest in their lives in recent years, Moken in Thailand appeared to be both researcherweary and also researcher-savvy during our fieldwork. This is not to claim that Moken are purposefully deceptive, rather it is to point out that many members of the community are consulted about their lives so frequently that they have come to know what to say and how best to communicate their interests to the stream of visitors they receive, including the authors of this article. This is important because it recognises the possibility of agency among the Moken in shaping how they are represented to those seeking to assist them and the ways in which this representation can obscure some of the realities of contemporary Moken life.

This article is divided into four sections. The first introduces the Moken and identifies the two recurring themes the ways they are represented, namely vulnerability and tradition. The second section provides further detail on Baan Lion itself and locates the village in a broader approach to reconstruction following the 2004 Asian Tsunami. The third section focuses on the question of why Baan Lion remains empty by examining the spatial dysfunction emanating from clashing perceptions of space/place between donors and the intended inhabitants. The fourth section continues this focus by exploring the limited possibilities for place-making in Baan Lion and relates these back to the spatial dysfunction and the persistence of notions of vulnerability and tradition.

\section{Moken: Traditional and vulnerable?}

The Moken are an ethnic group inhabiting the coastal areas and island archipelagos on the Andaman Sea from northern Malaysia, along the Thai coast and islands, to the southern coast of Myanmar and the Mergui Archipelago. A recent genetic study of Moken born on four different islands in the Mergui Archipelago posits that Malayo-Polynesian speaking Moken originated in coastal mainland Southeast Asia and moved into island locations several thousand years ago due to population and climate related factors (Dancause et al., 2009: 86). The total Moken population is estimated at around 800 in Thailand (and up to 2000 in Burma) (Arunotai, 2008). Accurate population figures are difficult to find for several reasons. First, Moken have been, and in some areas continue to be, mobile crossing between national borders and between coastal and island locations. Many Moken are sedentary and hold citizenship, particularly in Thailand, yet even so mobility makes compiling census data difficult. This is especially so in Myanmar where census data is very out-dated and Moken rarely 'show up' under the categories of citizens identified by the Government of Myanmar (Gravers, 2007). Second, many persons of Moken heritage are not necessarily counted as such in the compilation of national data. Some Moken have adopted non-Moken names and speak Thai or Burmese along with Moken. In other cases, particularly on the mainland, there are many ethnic Moken who do not speak Moken language. Intermarriage and new patterns of migration add to invisibility.

The Moken have been described using a range of terminology: 'coastal tribe' (Hogan, 1972), 'sea-gypsies' (Ferrari et al., 2006), 'sea nomads' (Arunotai, 2006), and increasingly 'indigenous' people (UNESCO, 2007). ${ }^{1}$ Scholars and advocates draw distinctions between the Moken, Moklen, and Urak Lawoi, seen as distinct in cultural practices, dialect, origin myths, area of habitation, and patterns of mobility. Arunotai argues that Moklen and Urak Lawoi are settled sedentary communities, whereas Moken maintain some nomadic tendencies and 'remain relatively traditional compared to other groups' (2006: 140). Thus, as Ferrari et al. (2006: 4) argue, in Thailand the Moklen have had greater access to citizenship rights than the more 'traditional' Moken. But as a consequence, it has been argued that these sedentarised Moken have been integrated into the nation/state to the detriment of their culture (Ferrari and Ivanoff, 2010). These authors note that these groups are abandoning the 'cultural markers of their exoticism', while at the same time re-traditionalising or representing as traditional in circumstances that are advantageous (e.g. tourism) as a form of 'identity dynamics' (Ferrari and Ivanoff, 2010: 2).

Limited recent research on Moken communities on the Myanmar side of the border adds to the confusion. There is general view that Moken, or Salone as they are known in Bamar language, on the Myanmar side are of more 'traditional' lifestyles owing to relative underdevelopment of the Andaman Coast and Mergui Archipelago on that side (see Ivanoff and Lejard, 2002; Sorenson, 1997). Thus there is always a more traditional group of Moken existing somewhere 'out there' keeping the distinctions in terminology alive. Arguments for a continued distinction between Moken and Moklen based on sedentary viz. nomadism are difficult to sustain following the dramatic rupture to lives and livelihoods brought by the 2004 Asian Tsunami. Inter-marriage, enculturation, and the decline of proficiency in dialects also play a role in blurring these distinctions (Dancause et al., 2009; Ferrari et al., 2006). The intricacies of these debates are beyond the scope of this article. We will use the term Moken, noting that a distinction between Moken and Moklen has utility but given the contemporary patterns of mobility, settlement, intermarriage and linguistic plurality it can be difficult to sustain empirically. For example, one family interviewed in Chaipattana on the mainland identified as both Moken and Moklen, had three houses (one in Chaipattana, one in Baan Lion and one on Ko Surin), had lineage from Burma and also Malaysia, regularly worked on both Ko Surin and the mainland, and spoke the Ko Surin 'proper Moken' dialect (interviews 20 February 2013). Another family interviewed in Baan Lion identified as 'Thai Mai' (new Thai) but then explained that they were Moklen. The family spoke Thai but their parents spoke Moken. Also they regularly fished with Moken people near Ko Surin (despite living between Baan Lion and the mainland), but that they were "not going there so much this season because of high tourist numbers and because of National Park restrictions on what they could catch there" (interviews, 22 February 2013). Many other families on the mainland and islands on the coast had similar complexities with regards to the question of 'exact' ethnic identity.

\footnotetext{
1 The Thai term 'Chao lay' (sea people) is used and may have derogatory connotations meaning primitive or backwards. Also, the term 'Thai Mai' (new Thai) may be used as a preferable ethnonym by the Moken/Moklen (Arunotai, 2007).
} 
It is important to stress that we do not dismiss the distinctions made by ethnographers; rather for the purposes of this article we need a term that will capture the totality of the respondents consulted and it becomes difficult to classify each respondent as either Moken or Moklen. There are certain characteristics of Moken life that may not apply to communities designated (mostly by outsiders) as Moklen and vice-versa. Yet for the sake of clarity we will use the term Moken. Moken is the term used along the Andaman Coast by NGOs, government offices, and tourist authorities, the Asian Development Bank, and as such has gained a certain clout. Moken was the term generally used by the respondents themselves, with several people making comments such as this: "Moken, Moklen, we are just the same! People [from outside] make us different" (direct quote from interview at Koh Phra Thong, 21 February 2013; similar comments obtained in Chaipattana, 9 January, 2013; Thung Wa, 19 February 2013). Due to the fact that Moken and Moklen people were generally self-identifying themselves under the broader term 'Moken', we felt it important to retain this characterisation.

Moken are represented through pervasive mythologies about their past and present. Cynthia Chou notes that Europeans based early accounts of 'sea nomads' on 'fleetingly observed' habits during sea voyages and conjecture by other communities (2006: 3$)^{2}{ }^{2}$ Ethnographic and linguistic studies became more common in the second half of the 20th Century (Hogan, 1972; Ivanoff, 1997; Sopher, 1977), and in recent decades discussions of Moken have become more common in literature by NGOs and various international organisations concerned with conservation and more recently indigenous and ethnic minority rights (Arunotai, 2002, 2006; UNESCO, 2007). Marine parks and tourism has transformed the Andaman Coast in recent decades bringing Thais and foreigners in closer contact with Moken communities and vice-versa, increasing interest in their lives and refashioning Moken as a tourist attraction.

After the tsunami the Moken began to receive unprecedented attention from state and non-state actors, particularly bilateral donors and NGOs seeking to rebuild communities and livelihoods, accompanied by a mini-boom in academic and NGO/International Organisation literature. This literature has focussed on two primary ways of representing the Moken: traditional and vulnerable. These will be discussed in turn.

\subsection{Traditional}

As more and more Moken settle in villages on islands and the mainland and seek livelihoods in the tourist industry, commercial fishing, and in various jobs on the mainland such as drivers, construction workers, and boat builders, the desire of researchers and activists to focus on the remaining 'traditional' Moken results in minimal attention to the changes in Moken lives and livelihoods. In effect there is perpetual search for traditional practices to preserve and document, while Moken life is moving on rapidly. This is not to say that these changes have eradicated marginalisation, but to stress the singularity of representation for communities living exceptionally plural existences.

There are several components to Moken traditionalism following the tsunami. The first is traditional knowledge utilised in response to the disaster. Accounts of the tsunami recount how Moken communities saw the sea retreat and noticed changes in animal behaviour and quickly evacuated to higher ground thus surviving the impacts of the tsunami better than other communities in the area (Arunotai, 2006, 2008; Lauer, 2012; Rungmanee and Cruz, 2005; Steckley and Doberstein, 2011; UNESCO, 2005).

\footnotetext{
${ }^{2}$ Colonial era administrators and anthropologists (often the same individuals) were exceedingly interested in the amount of clothing sea nomads wore and their alleged piratical activities (Chou, 2006)
}

This has led scholars and relief NGOs to speculate whether lessons learned from the Moken response can be translated into disaster management policy and practice in a climate change era (Arunotai, 2008). This story has spread rapidly among NGOs and relief organisations, yet little attention is given to the Moken communities devastated by the tsunami-including those resettled in Baan Lion. Many Moken on boats and in the erstwhile village of Pak Chok, a relatively exposed and flat area of coastline on Koh Phra Thong, lost their lives and/or homes, whilst those on Koh Surin, a steep island with the settlement built on a less exposed bay, were able to flee uphill when the water rapidly receded. Clearly geography played a role in the distribution of loss, yet this spoils the narrative somewhat.

The second is the exceptional status of Moken when compared to other communities affected by the tsunami. These accounts stress that because of their traditional lifestyles the Moken have to be treated with special care during relief efforts (Ferrari et al., 2006). It is here that Moken are reconstructed as indigenous peoples and entitled to (or perhaps deprived of) special and differentiated rights. Scholars and activists argue for increased and purposeful inclusion of Moken in decisions over natural resource management, access to excluded marine areas, and reconstruction (IUCN, 2006; UNESCO, 2001, 2007).

The third is the fragility of Moken traditions, perpetually on the edge of eradication. After the tsunami there have been renewed attempts to save Moken traditions, and by extension the entire ethnic group, before they are assimilated into other societies. One group of filmmakers from Norway have launched Project Moken (www.projectmoken.com) that aside from a documentary has an interactive web portal where visitors can experience the 'unique and fascinating nature of their 3500-year-old-culture as being one with the ocean.' The web portal also enables visitors to purchase the documentary and high-quality photographs of Moken to support the cause. It also enables visitors to sign up to sponsor tree harvesting for traditional boat building, enabling visitors to 'save the Moken culture' and informs visitors that the Moken's 'unique culture and maritime knowledge is under serious threat from globalization and local authorities.' Notably the community featured most prominently is the readily accessible and traditionally packaged community on Koh Surin. While well intentioned this shows the strong desire of outsiders to construct a traditional and endangered community under constant threat. Moken agency and capacity to cope with change is completely discounted and un-traditional lifestyles of Moken receive little attention or legitimacy.

Before moving on it is important to note here that the stereotyping of Moken is not only reproduced by dominant national communities and institutions, in this case Thai people and the Thai state, who perceive the communities to be backward and primitive, but also by the supporters and advocates for these communities. The latter could be read instrumentally. In other words, supporters overly emphasise Moken vulnerability and uniqueness to corral donor funds that flowed to the region following the tsunami. Yet this is difficult to determine for certain. What is also unclear from the literature, and what became clearer during research for this article, is the role that members of the Moken communities in Thailand have in reproducing stereotypes to Thai and foreign researchers and NGO workers.

\subsection{Vulnerable}

Aside from the cultural vulnerability derived from being traditional, the Moken are depicted as politically, economically, and physically vulnerable. Political vulnerability rests on citizenship status. For example: '... the Moken along with several other indigenous peoples continue to be land-less and state-less beings 
without formal help and support' (Arunotai, 2002). While historically affected by persecution, lack of citizenship status, non-recognition of land entitlements and economic exploitation, the Moken have also adapted to changing conditions. Many of the Moken people interviewed during our fieldwork had become Thai citizens in recent years (or in past decades) and had land title, housing, and were receiving various state and non-state benefits (e.g. education, health care, income from tourism ventures). It is also true that other Moken have not become citizens, especially non-sedentarised Moken, and while the tsunami did extend citizenship to more Moken than before (as Thai authorities recognised that many people had lost their papers in the disaster, thus accepting the claims of many applicants for a period), some do remain without formal citizenship from either Thailand or Myanmar. Some family members of interviewees that we met, for example, held a 'zero card' which provides limited rights of residency whilst waiting for citizenship to be processed.

Economic vulnerability casts traditional skills as an impediment to adaptation as they lock Moken into certain occupations and methods of production unsuited to contemporary livelihoods. A survey of communities on the Andaman coast following the tsunami provides some insight into the ways vulnerability is experienced by the Moken and the ways this is perceived (Nidhiprabha, 2007). The report notes that the Moken were the community worst affected by asset losses (many lost important assets like boats and houses) and lost family members; despite rhetoric about folklorebased disaster response strategies. The survey also notes that comparatively, the Moken suffered less income loss than the other groups (likely due to their often subsistence-based activities and lower currency held) and relatively few changed occupation. As a result the report assumes that 'many of them were not only less dependent on the market for their incomes, but with limited skills, may have also had fewer opportunities to move into other jobs' (Nidhiprabha, 2007: 29). The statement typifies the post-tsunami portrayal of Moken vulnerability. It portrays generic 'traditional' skills that make adaptation difficult. Even where distinctions are made between sedentarised and nomadic Moken, economic vulnerability tends to be generalised to apply to all (see for example, Nidhiprabha, 2007), overshadowing adaptation. Furthermore, it underestimates the extent of market-integrated activities such as fishing, squid trap building, squid trapping, tin mining, manual labour, and other activities noted during interviews. We would argue that the lesser impact on income lost reflects potentially lower material wealth to begin with and the capacity of Moken to adapt to rapidly changing circumstances, as will be discussed further below.

Physical vulnerability underpins reconstruction that focuses on safety and security. Like the community relocated to Baan Lion, the Moken community in Thung Wa village near Khao Lak on the mainland were relocated inland to 'safer' areas following the tsunami (Lebel et al., 2006). This left the community far from the sea, eroded land rights they had won in the old village, and the construction of a German Government-funded hospital on the site of the old village made return impossible. This demonstrates the uneven and often illogical nature of reconstruction along the Andaman Coast, shaped by a lack of coordination, corruption and competing donor and government interests. In Thung Wa land was deemed unsafe for Moken habitation but safe enough for a hospital. As Lebel et al. (2006: 128), note vulnerability was central to the way the entire coast was restructured:

...in this state vision fishers were invisible. The Department of Public Works and Town Planning formally enacted its new land use plan for Khao Lak on 30 May 2005 (essentially for tourism projects) and required that construction must be at least 30 meters from the highest point of the ocean tides effectively eliminating all fisher villages between Khao Lak and Baan Nam Kem.

It is not our intention to criticise reconstruction per se, indeed post-disaster reconstruction has been instrumental in reducing risks and saving lives in locations throughout the world. Our focus is on this particular village and the puzzle of its lack of habitation. There have since been a number of critiques of this use of 'safety/ security' in with post-tsunami reconstruction (see Kennedy et al., 2008; Hyndman, 2007) and post-disaster reconstruction more generally (Barakat and Zyck, 2011; Bosher, 2011; Oliver-Smith, 2007; Williams and Jacobs, 2011). Following the 2004 tsunami, reconstruction activities in the affected countries were often undertaken using the catchphrase "build back better". Much of the new construction was intended not simply to replace what had previously existed, but would be of a 'superior quality', and of course be safer from future tsunamis. In such cases, communities have had differing reactions to the homes provided to them. Nidhiprabha (2007: 34) notes that:

There have been reports both in Thailand and in other tsunamiaffected countries of many instances where communities have not been happy with the new houses. Arguably, people who have been greatly traumatised by the experience of a disaster can react to a new home in different ways. In their mentally depressed state they may view the new house as being an inferior replacement even if it is in fact a superior structure. Alternatively, they may rate it as better because they have lowered their expectations due to reduced circumstances, with unemployment, debt, and so on as pressing factors.

State of mind is one potential factor and Nidhiprabha notes that their analysis is far from conclusive. We would argue that a range of other cultural factors and livelihoods variables must be considered regarding satisfaction with the appropriateness of the housing provided by the reconstruction projects. Specifically we note that the imposition of donor ideas about what represents 'superior quality' has resulted in a village which appears to be quite different to the ideal of usable/liveable space for Moken, and this results in severe challenges for place-making. To illustrate, we examine the Baan Lion community in detail.

\section{Baan Lion: Rebuilding lives}

Post-disaster reconstruction has taken place along the Andaman Coast through a mixture of Thai public funds, international donor funds, and private funds (mostly for rebuilding resorts). Different donors/funders have focussed on different parts of the coast and even different individual villages. This has resulted in unevenness in terms of quality, functionality, and speed of construction in different parts of the coast. As Assavanonda (2005) notes in their review of post-tsunami housing in Phang Nga province of Thailand (one of the most heavily damaged provinces), a total of 2634 housing units were built for affected families, under many different state and donor funded projects, with highly variable results in terms of quality, location and suitability. Baan Lion makes for a compelling case study of post-disaster reconstruction as it reflects the differing notions of space between donors and the local community and the limited possibilities for place-making by intended inhabitants. Following the 2004 tsunami the Lions Club has been involved in reconstruction efforts in Southern Thailand. ${ }^{3}$ The Lions Club International Foundation (LCIF) was awarded more than $\$ 15$

\footnotetext{
${ }^{3}$ Notably LCIF is a charitable organisation, but is not a 'development agency' in the true sense, largely relying on volunteers, many of whom are businesspeople in Bangkok, to volunteer their time towards these projects. Although they provide 'disaster relief' to many projects globally it is unclear what experience they have in post-disaster housing projects.
} 


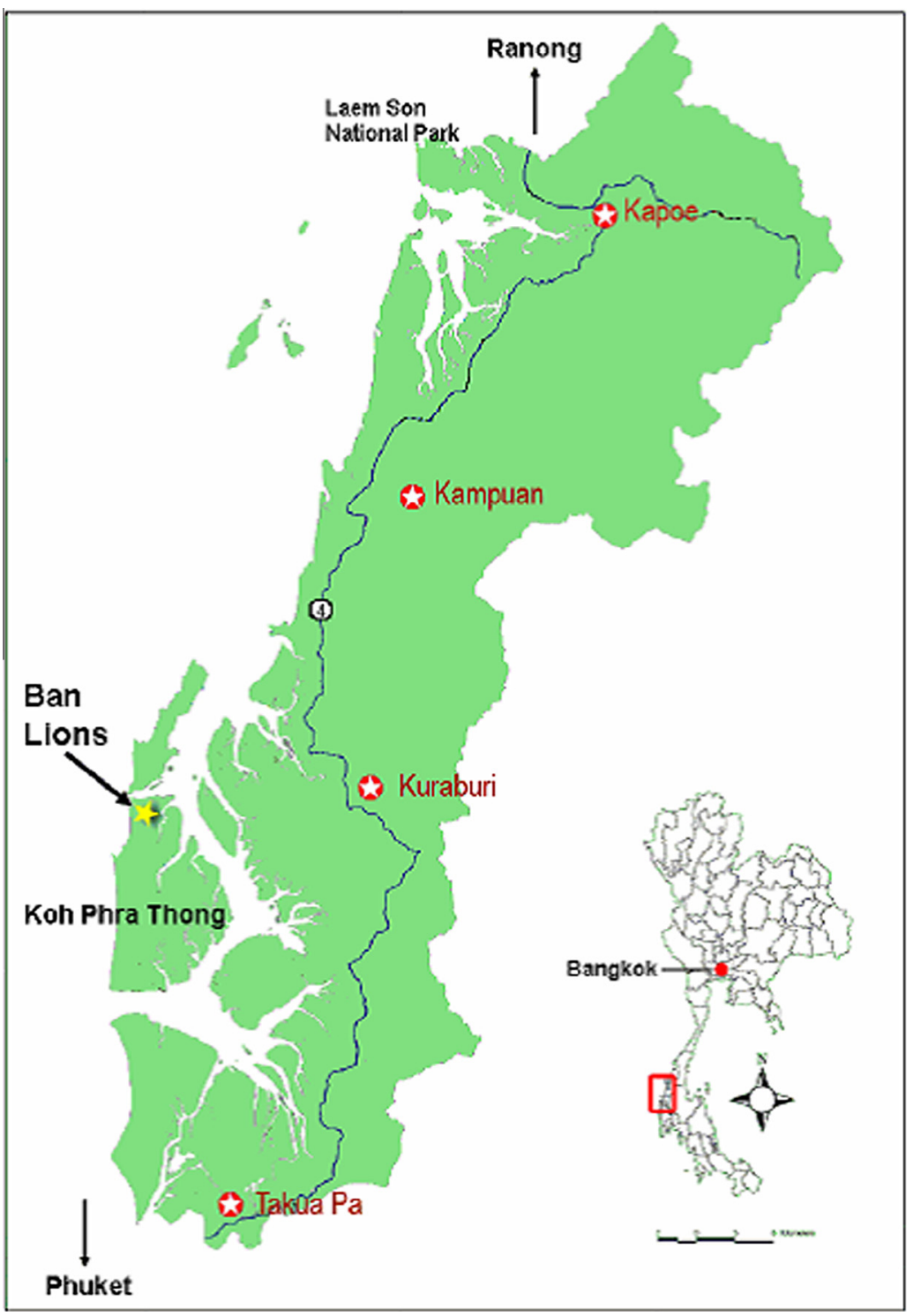

Fig. 1. Map of Kuraburi and Koh Phra Thong:

million for long term reconstruction efforts in Thailand, India, Indonesia and Sri Lanka, with most of these completed by 2009 (LCIF, c2009). Our research focussed on one of these reconstructed villages: Baan Lion, ${ }^{4}$ on Koh Phra Thong Island, Kuraburi Amphoe (District) in Phang Nga (see Fig. 1).

Baan Lion was built to house inhabitants of the village of Pak Chok, which was completely destroyed by the tsunami. The new village was built in two main phases with approximately half of the houses completed in 2007 and the second half completed in 2009. There are approximately 160 houses in the village. According to current and former inhabitants of Baan Lion, the Lions Club reportedly had two phases of construction where they primarily built houses and then subsequently withdrew the third phase of funding for additional infrastructure (interviews, Baan Lion, 2122 February 2013). In February 2013, local people estimated that only about 15 houses were regularly occupied.

In their 2008-2009 Annual Report, LCIF claims that 'LCIF and local Lions have not only rebuilt communities, but have also restored the lives of people impacted by the tsunami.' (c2009: 10)

${ }^{4}$ The village is named Baan Lion or Baan Lions after the Lions Club.
Yet despite the rows of new two-storey houses the village has been depopulated and the majority of houses are empty. What explains this phenomenon? In addressing this question we focus on two related development failures: (i) spatial dysfunction, and (ii) limited possibilities for place-making. It is important to note that although we are critical of the outcome of the reconstruction at Baan Lion we do not attribute blame to LCIF or local Lions Club as such. Rather we seek to demonstrate how clashing notions of space have resulted in the near-empty village. It must also be noted that we did attempt to visit a representative of the local Lions Club resident on Baan Lion in 2012 and 2013, yet their compound was empty and oddly surrounded in barbed wire.

\subsection{Spatial dysfunction}

There are four key issues in the reconstruction of the village that have created spatial dysfunction: layout, house design, functionality, and location on the island. At the core of these issues are clashing perceptions of space between donors and the intended inhabitants. There is a rich literature on the on post-disaster reconstruction and other forms of resettlement (following large-scale 


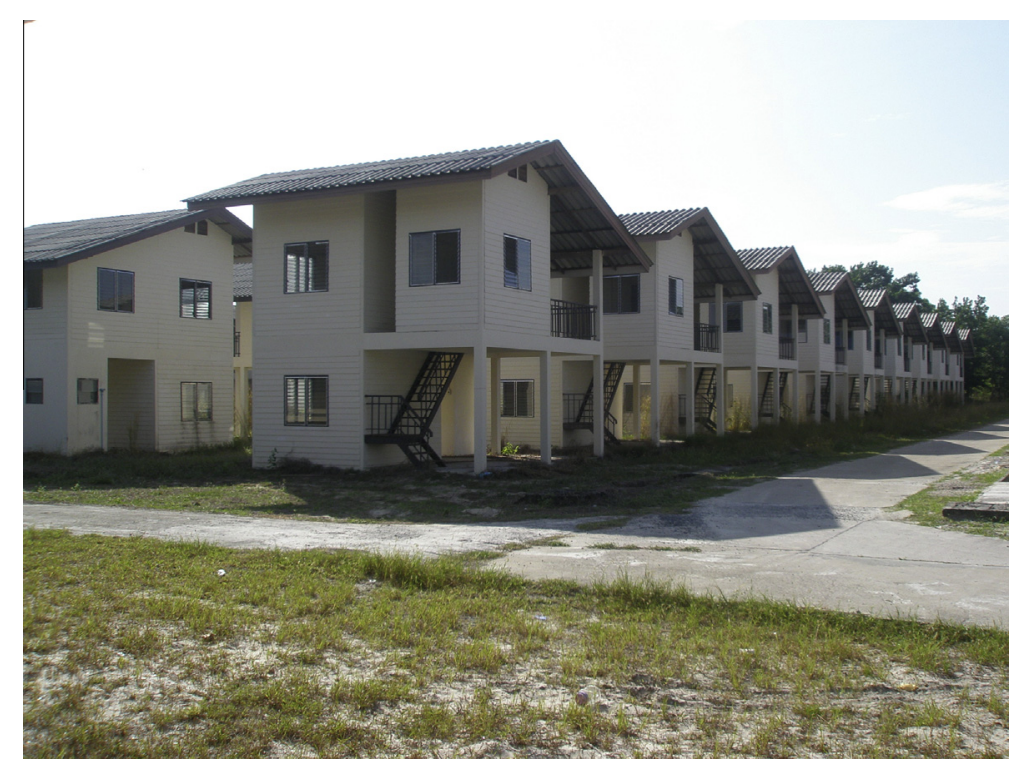

Fig. 2. The empty houses of Baan Lion arranged on a grid. Source: author.

development projects and civil conflicts) that details some of the many challenges including: enabling local participation, procurement and corruption, recreating social worlds (Chang et al., 2011; Davidson et al., 2007; Ganapati and Ganapati, 2008; Hilhorst et al., 2010; Oliver-Smith, 1991a). Informed by this literature we argue that donor perceptions of space dominate the logic of the new village. When the intended inhabitants have been considered, in this case the Moken community from Pak Chok, the planners of the village have focused on supporting traditional livelihoods and physical vulnerability: both of which indicate a limited understanding of contemporary Moken life.

\subsubsection{Layout}

Baan Lion was built on abandoned shrimp ponds a few hundred metres east of the original Pak Chok village on the northern end of Koh Phra Thong. It appears this site was chosen because the land was available for purchase and disused. Inhabitants told us that the first construction activity was a concrete helipad for a senior official from Lions Club to land and inspect the site. This remains unused in the centre of the village. Following this, several rows of two-storey houses were built along parallel rectangular grids (see Fig. 2). The pattern of construction in parallel streets is typical of Western, especially North American, town planning. ${ }^{5}$ The grid is not a wholly foreign phenomenon and has been readily adopted in Thailand by planners and government agencies. Indeed solely identifying such planning as western ignores the popularity of parallel grid planning in Thai towns and villages especially those developed during the second half of the twentieth century. The important point to note is that this type of planning is very different to the ways Moken and other coastal communities build their villages.

Houses are close together and arranged in symmetrical rows on either side of the paved streets. In what appears to be a kind of village square, there is a large plaque acknowledging donors, a statue of the 'Father' of the Royal Thai Navy, and a lookout tower. Notably, the sea is not visible - similar criticisms about grid layouts and the lack of access to the sea have been made of other post-tsunami villages on the coast (e.g. Baan Nam Khem and the Rotary project at Pru Tiew, see Assavanonda, 2005). This layout is in stark contrast

\footnotetext{
${ }^{5}$ We were informed by one of our interviewees that Lions wanted to name each of the streets after the countries that had donated funds for the reconstruction. Previously none of the small paths on the island had been named.
}

to the two other villages of comparable size on the island: Thung Daap and Tha Pae Yoi. Both have a main road/path roughly parallel to the coast with houses oriented organically/irregularly on either side of the road - typically with family units built next to each other with space in between, gardens, fruit trees, and sufficient land for other uses (like squid trap building or sand sifting for tin). Houses are close to the coast so that there are only short distances for locals to carry loads or access boats.

One respondent indicated that the Tambon (subdistrict) Administrative Office (TAO) had made comments to the effect that they did not want to 'step on the Lions Club's toes' regarding the planning of the project. As a consequence, there has been inadequate coordination between the Lions Club, TAO and the community, manifest in several ways. First, no waste disposal service was planned for the town and though the TAO provides bins for each house there is no collection service. Locals have created their own makeshift landfill a short distance out of town. Second, septic tanks were put in but in some cases were cracked and leaked from the beginning. The town does not have a fixed water supply, but has individual tanks provided by a different relief agency and the TAO to catch rainwater for domestic use.

\subsubsection{House design}

Respondents in Baan Lion indicated that houses had been designed and constructed poorly, using cheap and flimsy materials, poor workmanship and with little consideration of local lifestyles and livelihoods. The houses are built very close to each other with very small yards of only approximately 5-10 square metres. For houses built in the middle row in both the first and second phases of Baan Lion, the rear of each house backs onto the rear of the house behind. For houses on the outer rows the back of their houses is exposed to scrubland and mangroves with little space to expand outwards for a kitchen as with other houses (some of these were also evidently more prone to termites). All houses front the street.

The two storey houses are all built identically with three bedrooms upstairs, an open living/dining area downstairs, a bathroom (but no kitchen in their original state - remaining residents have often built a kitchen in the small area behind each house), and one bedroom downstairs. Because the houses are built on concrete slabs, unraised on the sand with no apparent piers, the whole lower storey floods during heavy rainfall (interviews and observations, 
Baan Lion, 10-11 January 2012 and 21-22 February 2013). In many of the unoccupied houses it is evident that heavy rains have brought many cubic metres of sand through the ground floor of the houses. Many of the houses in other parts of the island and nearby Koh Surin are built on stilts to avoid this and to allow ventilation.

During the monsoon season there is also considerable leakage from the roofs inside the houses and between the cladding walls. Because the unraised concrete slabs are laid directly onto the sand there is rising damp in the wet season and there have been septic tank overflow problems. Many of the steel rails on the stairwells and upper floor are already rusting and cladding has cracked in some houses (interviews and observations, Baan Lion, 10-11 January 2012 and 21-22 February 2013). Timber rafters in a row of houses near the village edge have been infested with termites and the roofs appeared to be sagging dangerously (and these houses are now unoccupied). One respondent indicated that they liked living in the houses at Baan Lion because "we don't have to build them every 3-5 years or so" as is the case with traditional Moken houses (interview, 22 February). However, we observed that the respondent's house was very close to those infested with termites, suggesting that it might only be a matter of time until they might also have to move.

In our discussions with residents we asked if the Lions Club representatives had seen these wet season issues and they indicated that they had only come to tour and inspect the village in the dry season. Residents noted that the Lions Club had come in 2012 but just toured the village - no appointments were made to discuss things with the residents (interviews, 22 February 2013).

There are also privacy issues as a result of the grid-like plan and housing design. Built within a few metres of each other and aligned along a grid, it is possible to see into the private living areas of all houses in each row. The houses were built with glass windows but without curtains - most have sheets or blankets hung across windows for privacy. In addition, several residents had attached woven mats or planks of timber to the underside of the open stairwells to preserve the modesty of women, who often wear sarongs, when they are using the stairs (see Fig. 3). By comparison, most of the older houses on the island are built with timber or woven-leaf shutters on every window, there are usually smaller windows, and the houses are oriented for privacy by distance and trees. Given the considerable literature and stereotypes about the 'timidity' of the Moken people ${ }^{6}$ it is surprising that privacy was not more adequately considered in the planning of the village.

\subsubsection{Functionality}

Respondents who had been given houses in Baan Lion but spent most of their time residing in other villages (on the mainland, on Koh Phra Thong, and on Koh Surin) frequently raised poor functionality as a reason for leaving Baan Lion. The houses are difficult to use in the same ways they were used to. First the space is not sufficient enough to perform everyday tasks common for fishing communities: drying nets, fixing nets, building squid traps, sorting through gathered shellfish, nor for other livelihood activities such as sifting sand for tin deposits (Ferrari et al., 2006; interviews and observations, Baan Lion, 10-11 January 2012 and 21-22 February 2013).

In other Moken villages, sedentarized Moken build family compounds with far more space for cooperative work. In Thung Dap, located on Koh Phra Thong, Moken families live in larger settlements with houses arranged around an open area. The arrangement is far from orderly when compared to the grid of Baan Lion.

\footnotetext{
${ }^{6}$ This assumption is still popular. For example, Rungmanee and Cruz suggest that it has been difficult for Moken to find work following the tsunami because they are 'shy of outsiders' (2005: 21).
}

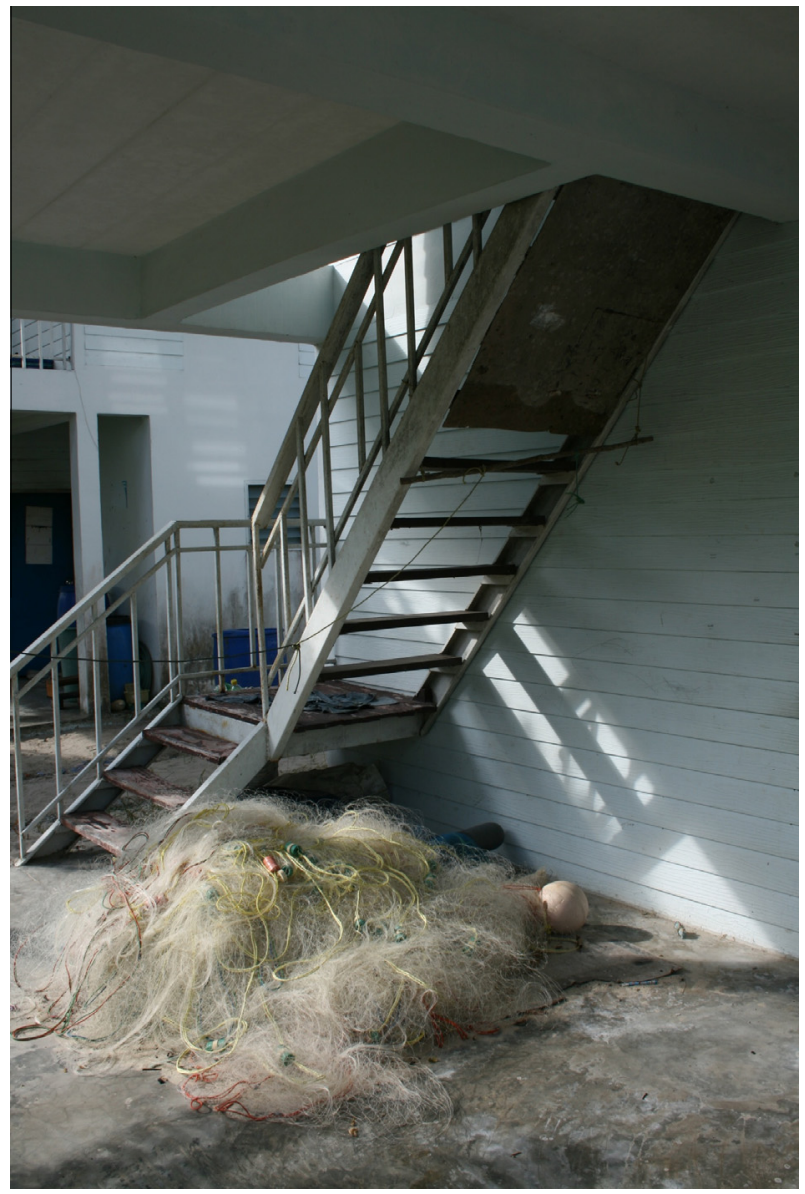

Fig. 3. Small alterations recall the old village. Source: author.

Yet the space in between the dwellings is far more functional. Wooden houses on stilts provide shade for tasks performed under the house (also noted in positive reports about the post-tsunami village Baan Tub Tawan. Assavanonda, 2005; interview, 21 February 2013). The more spread-out settlement has space for making squid traps and stacking them in piles awaiting collection from brokers. There is space for sifting sand for tin. Sand is delivered by trailer and sits in a large mound within the compound. There are a number of stages to the process and these require a number of purpose-built wooden troughs for sifting the sand, shaded areas to sit while sifting, and sheltered areas to store the finished product. The houses at Baan Lion provide no such space. Nor did they even provide a proper open kitchen area - a massive oversight.

In Chaipattana, a village rebuilt on the mainland with funds from the Thai Red Cross and the King's Foundation, the houses are also built in rows, but there is more space around them. In the yards there is enough space to have a small covered area to shield the sun and divide the different steps of the trap-building process among family members spread out across the yard. Furthermore it is easier to get materials and sell finished traps. A supplier comes to the village and bamboo and thin sticks gathered from other parts of the mainland. On Baan Lion the sticks are more expensive and they are not available as often and buyers have stopped coming. Interview responses in Chaipattana and Thae Parat suggested that for many of these reasons, people had not settled in Baan Lion, preferring to use their house on the mainland (interviews, 19-22 February 2013).

In Baan Lion families are dispersed in different parts of the village as they were allocated. Further as the village has depopulated 
and as houses allocated have not been lived in, the proliferation of empty houses denies this shared space. With no neighbours or family members to assist in shared tasks the appeal of living in Baan Lion is limited. Families then leave the village, which reduces the appeal for other families. In February 2013, the owner of the only general store in Baan Lion was making plans to close and move to Tah Pae Yoi, further impacting the remaining residents (interviews, 21-22 February 2013).

The second main problem comes from space utilisation in Baan Lion itself. The desire for order and neatness evident in the layout of the village and the house design is also evident in how residents have been instructed to use the space. Residents who initially moved into the village were building squid traps in ground floor space and their yards. Respondents reported to us that representatives from the donor agency (it was unclear to villagers the official status of the visitors or which agency they were representing) came to the village and told them to clear their squid traps, tidy their yards, and create gardens with plants. Though it is difficult to determine when and how this desire for orderly, clean space is enforced there is a sense among residents that they cannot utilise their houses as they would in their old village. Some of the NGOs based in Baan Lion have held a garden competition and organised waste clean-up days. In response some residents have planted gardens; however the sandy soil and flooding that occurs during the monsoon makes them difficult to maintain much less replace the income from traps (interviews and observations, Baan Lion, 10-11 January 2012 and 21-22 February 2013).

Despite the directives for order, remaining residents in Baan Lion have modified their dwellings in ways that defy the uniformity desired. For example, one house had a boat in the front yard. Others had fishing nets and squid traps (see Fig. 3). In one house residents had built a makeshift shelter using sticks and hessian to extend the shaded area at the front of the house. In another, residents had built a chicken coop in the front yard. One particularly notable amendment was a door made of palm fronds placed over the top of the wooden door. A shared fish drying rack was built in an open area of grass next to the helicopter pad and the now closed school, though these modifications were a small feature compared to the rows of empty houses, the empty school, and the large community hall built for the community that never materialised.

Notably, the school and hall were built by the Swiss Agency for Development and Cooperation (SDC) and they have since acknowledged that they may be oversized for the 'forecasted population strength' (Kritsanarangsan and Scheuer, 2008).

\subsubsection{Location}

After the tsunami safety became a major concern for rebuilding villages. Reducing vulnerability to future tsunamis and other extreme weather events is a key donor objective in post-disaster reconstruction (Kennedy et al., 2008; Wong, 2009). This is understandable and it is not our intention to criticise this as an objective. What is interesting in the case of Baan Lion is the way that donor perceptions of safety clash with local perceptions of accessibility (see Fig. 4). ${ }^{7}$

Baan Lion has been built back from the coast with a road of approximately $200 \mathrm{~m}$ from the aforementioned pier constructed on a protected inlet. Interviewees in Baan Lion indicated that this site was chosen for two reasons: safety and because of cleared land

\footnotetext{
7 This is also noted of the village re-built by agencies on Koh Surin: 'new houses have been laid down into the forest too far from the water's edge, lined up on a grid, built too low to the ground and too close together. The result is poor ventilation and sanitation, as well as obstructed views to the sea, even though clear visibility is essential both for monitoring sea conditions and for daily activities along the coast' (Derek Elias of UNESCO Bangkok, cited in Mercer et al. (2007, p253)).
}

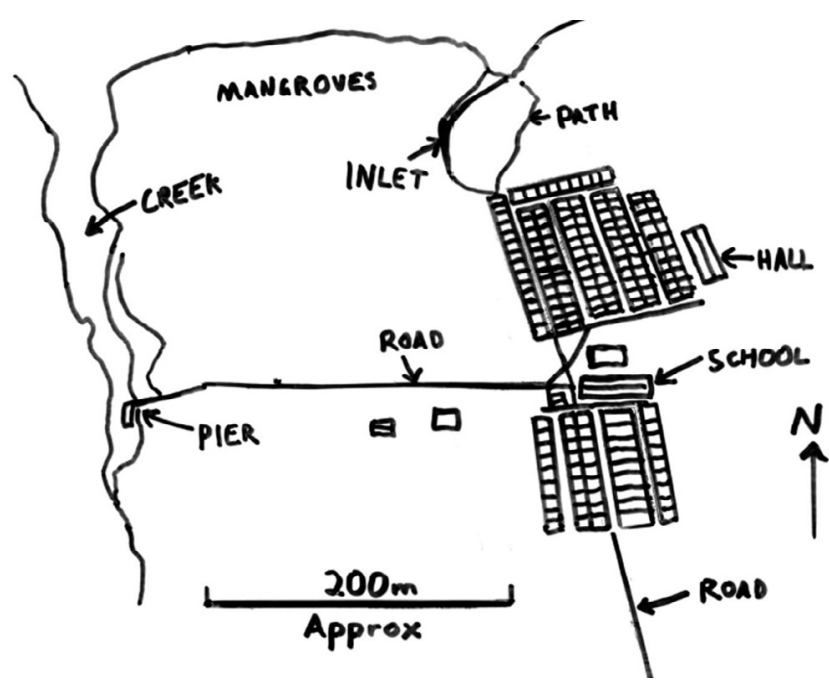

Fig. 4. Diagram of the village layout in Baan Lion. Source: author.

available for purchase. Due to the distance between the town and the pier, loads from the larger boats have to be transported along this pathway manually or by a motorbike with a sidecar which needs to be hired at additional cost. As a consequence, a shorter path through some mangroves has been cleared by the locals and it is evident that boats were leaving Baan Lion from a makeshift pier some $30 \mathrm{~m}$ from the northern edge of Baan Lion opposite the smaller island of Koh Rah, rather than west out to the Andaman Sea as in the former village of Pak Chok (the direction of their primary fishing grounds, but also the direction the Tsunami came from). One interviewee noted that they had "never used the pier, and liked launching their boats from the [small inlet at the] corner of the village" (interview, 22 February, 2013). Smaller fishing boats are tied in this makeshift inlet/pier and locals can access the ocean from there. This section of Baan Lion was also more heavily habited than other sections with the exception of an enclave surrounding an NGO-supported Community Conservation Centre in the middle of town, and some NGO housing. We observed residents utilising the closer makeshift inlet for loading and unloading boats into their small yards.

Different perceptions of risk are also evident here. For donors the greatest risk to locals comes from another tsunami or extreme weather event. The new village appears designed to prevent the sea from destroying the community once again. Whereas for locals everyday life contains numerous risks and uncertainties, whether it is the risks of earning livelihoods at sea, the risks of traversing international maritime borders and national park boundaries, or the uncertainties of irregular income, poor health, and land tenure. In other words while another tsunami remains a looming risk and one that donors have done their best to offset with the location of the new village, the lack of access to livelihoods and to health care is just as significant a risk for the people in the village. Several Moken we met during fieldwork who resided on the mainland despite having been granted houses in Baan Lion iterated that there was more work on the mainland and it was "better to be closer to health care" in the district capital of Kuraburi and because "our kids go to school here now" (Interviews, Baan Chaipattana, and Baan Thep Prathan respectively, 20 February 2013).

A related issue is the closure of the school at Baan Lion. It is difficult to fault donors for this. Now closed, the school in Baan Lion makes for an evocative sight. The large cement building sits on raised pillars. Steel playground equipment is stacked and broken chairs are scattered on the ground level cement floor. The blue shutters are all closed. The building itself is very large, far too big 
for the needs of the village, though perhaps planned with the hope that Baan Lion would be fully occupied. It overlooks the open grass area and helicopter pad on one side and the largely unoccupied second phase on the other, both lasting testament to some ques-

It is important to note that the school was functional in the past. A number of contentious issues emerged between the teacher and the community that are beyond the scope of this article. However this led to the teacher leaving and not being replaced. With so many families leaving Baan Lion student numbers also declined, making it difficult to justify a replacement. Residents from Baan Lion are now forced to drive their children by motorbike about $10 \mathrm{~km}$ across a windy path to the eastern side of the island to the school at Tha Pae Yoi at considerable cost. Notably Tha Pae Yoi's school was also built by donors and is so large that only one floor out of three is used. Parents with smaller children have to own a motorbike, or pay for fuel to be taken on one of the motorbikes or alternatively take their boat to school. Other families leave their children with relatives on the mainland so they can go to school there or leave the village altogether. Recently, the village head (Kamnan) of Baan Lion has arranged for a motorbike sidecar driver to make a daily return trip to Tha Pae Yoi with the 2-3 remaining children in Baan Lion (interview, Baan Lion, 21 February 2013).

Clearly there are clashing understandings of space operating here. Donors and planners have built a village that is 'safer', but largely dysfunctional. Where Moken lives and livelihoods have been considered, they are viewed as subsistence fishers rather than a complex community undertaking a range of livelihood activities that require closer connection to markets. As the village has depopulated the possibilities of creating place out of this spatial dysfunction are more and more limited.

\subsection{Limited possibilities for place-making}

The concept of place-making, drawn from Henri Lefebvre's dialectical approach (1991) to everyday life and the social production of space provides a loose framework for analysing the limited possibilities for place-making in Baan Lion. Theorists of space and place, particularly in human and political geography, usually draw a distinction between the two, wherein space is rootless and shaped by external forces and place is rooted and shaped through human agency to produce and reproduce a social and moral meaning (Agnew, 2011: 322). As Massey notes,

. the specificity of place... derives from the fact that each place is the focus of a distinct mixture of wider and more local social relations and, further again, that the juxtaposition of these relations may produce effects that would not have happened otherwise (1993: 69).

Often the struggle to create place out of space is a counter-hegemonic struggle, a concept particularly apt in the context of the Moken and their contentious relationships with national park authorities and protectors of state borders. Yet clearly distinguishing between space and place can be empirically hazardous, and even the most localised place is usually affected by external influences of the space in which it is embedded (Merrifield, 1993).

Here we adopt John Friedmann's use of place and place-making as an entry point to understanding the de-population of Baan Lion. For Friedmann place-making occurs when a material space is inhabited and allows patterns and rhythms of life to develop. Friedmann, using examples from China, arrives at seven propositions for understanding place-making (2007: 172). First, placemaking is a social process characterised by contestation. Place is not granted but made through social practices which often invoke competing claims over material space. Once created, places are not fixed but subject to continued contestation. Second, habitation of material space leads to patterns of everyday life centred on places of encounter where rituals of life are performed (such as parks, markets, churches, restaurants, houses). Third, places are impermanent and undergo changes over time. Fourth, the rituals of everyday life offer a sense of security and stability. Fifth, the autonomy of place is illusory and subject to regulation, for instance by property owners, authorities, or donors. Six, regulation affects different members of the community in different ways and while contestation is common, solitary cannot always be assumed. Finally, the importance of village and neighbourhood places can diminish over time as social and economic networks widen.

With these propositions in mind, we argue that Baan Lion demonstrates an attempt to create place by planners with limited engagement by the subjects of this intervention. The donors and planners of Baan Lion aimed to 'rebuild' communities and 'restore lives', yet the near empty village suggests that community has been fragmented and that lives are being rebuilt elsewhere. While it is difficult to dispute the necessity of a focus on safety and shelter, space was constructed based on notions of Moken vulnerability and on assumptions about livelihoods based on the sea and subsistence. As such there are limited possibilities to engage in social processes as essential networks for Moken life bypass Baan Lion (i.e. social engagements that are part of normal life cannot be sustained - school, markets, employment and livelihoods-focused activities are all diminished or made more difficult), making Friedmann's patterns and rhythms of life virtually impossible to establish.

The isolation of Baan Lion makes it difficult for Moken to access exchange networks essential for established livelihoods and what we refer to as 'new' livelihoods. Without networks there are limited flows of people, goods, and encounters necessary to establish place. Moken are known as fishers, yet little consideration was taken of their need to sell what they catch. Baan Lion makes anything beyond subsistence fishing difficult because there are few buyers, unlike in Tha Pae Yoi, on the other side of the island, or the mainland. Relative isolation also makes the cost of petrol for the boats much higher than other parts of the coast. Notably, boats had been provided by some NGOs post-tsunami, which are readily utilised by Moken for fishing and collection of marine species (e.g. a mollusc named Hoi Chuck Tehn). Depending upon the value of the species in question, in recent years much of the catch was sold at Kuraburi on the mainland and more distant markets including Phuket and Krabi, making stay at Baan Lion impractical. Some interviewees thought it preferable to return to a home on the mainland given the proximity to markets. As discussed above Moken are well known along the Andaman Coast for fashioning squid traps. Aside from the small yards, Baan Lion is not well connected by sea or by road and thus it is difficult to buy the materials needed to make the traps (bamboo and netting) from the travelling peddlers. It also means fewer buyers show up in Baan Lion, especially given the plentiful supply from Moken villages on the mainland and in the more accessible villages on Koh Phra Thong. The same pitfalls apply to tin sifting. Baan Lion is too far from the source of the potential deposits and the plots are far too small to make this viable.

The pursuit of so-called 'new' Moken livelihoods in Baan Lion is also difficult. From fieldwork it is clear that Moken livelihoods have been undergoing transformation for several decades, yet the persistence of the 'sea gypsy' mythology has obscured much of this transformation. While scholars and advocates focus on preserving Moken subsistence practices and traditional livelihoods, many Moken have been moving into wage labour. According to residents throughout Moken areas visited during fieldwork, wage labour supports basic needs and aspirations - both material and social 
(especially education for children). Such aspirations rarely feature in the depictions of Moken discussed above or in the minds of planners in the case of Baan Lion. Wage labour available to Moken is varied and most common in tourism, manual labour in towns, drivers, and commercial fishing as part of crews and fleets (especially squid catching and cleaning). Pursuit of these livelihoods necessitates new patterns of mobility, social and economic networks with other communities, and changing settlement patterns. This is most evident in the tourism industry. During fieldwork we met Moken from Koh Phra Thong working in tourist resorts as far away as Phuket (where there is also a local Moken community), and in the mainland towns of Kuraburi and Khao Lak. Others worked at hotels or resorts and at the National Park headquarters on Koh Surin.

The tsunami has brought new competition in wage labour markets, especially from the large numbers of Burmese migrants that have come to the coast and Koh Phra Thong to work in construction and on the piers. Ever since the Tsunami there has been a boom in construction on the coast - not just rebuilding hotels and infrastructure, but also adding new resorts as tourist interest in the Andaman coast grows. Many young Moken have been able to secure jobs considered slightly better than those available to Burmese migrants: especially in the tourism industry. Interviewees put this down to younger Moken speaking Thai well, often at a higher proficiency than Moken language. This alone caused much lament among older Moken interviewees, who also felt that younger members of the community had very different aspirations to them. As one respondent in Thep Pharat village put it when discussing his son, he wants a 'Thai life', something that could not be realised in Baan Lion (interview, Thep Pharat, 9 January 2012). However it is possible to over-determine a firm generational distinction here. Many middle aged Moken, particularly men, discussed their preference for wage labour and 'new' livelihoods as well. Baan Lion is not well suited to pursuing these livelihoods. There are very limited networks for finding jobs, there is no longer a school, there are no buyers and no peddlers, and food and fuel are expensive (interviews, Baan Lion, 21-22 February 2013).

Habitation is essential to place-making, yet Baan Lion is nearly empty with only 15 houses occupied. As discussed above as people leave the village or fail to take up houses granted to them, the place becomes less attractive to other residents; both current and potential. The over-supply of housing makes the situation worse, as creating a sense of place in the disparate spaces that are inhabited in the village is more difficult than in the smaller villages on other parts of the island and on the mainland - even when those on the mainland are more like neighbourhoods of larger towns. In Baan Lion, the problem is not just that intended residents leave or never arrive, but that a different set of inhabitants are the only constant presence. Despite the low occupancy in the village and the transient use of homes by some residents, the community that still reside here have taken on a number of new roles. Nearby on the island small bungalow-style hotels and the upmarket Golden Beach Buddha Resort also hire some of the remaining residents of Baan Lion (or residents from other towns on Koh Phra Thong). Workers at the Resort stay in Baan Lion at night-time, before leaving early in the morning to go to work. Yet these workers are barely seen around the village, their presence only noted when they start up their motorbikes in the pre-dawn before heading along the islands lone paved track to the beach resort. Time spent in the tourist resorts of Andaman Thailand has introduced many Moken to the possibilities of making a living in service industries. With support from local NGOs on the mainland encouraging eco-tourism and homestays, Baan Lion is now home to an increasing number of houses offering temporary/tourist accommodation, with supply far outstripping the meagre demand. Respondents running homestays suggested that if Koh Phra Thong gains official national park status, a decision that is currently pending, then more guests will come. This has created a bizarre reality in Baan Lion, where accommodation for seemingly non-existent visitors sits alongside rows of empty and rapidly dilapidating houses.

Others working on the mainland come and go, staying in Baan Lion on occasion. In some houses tenants, many of whom are Burmese nationals, rent (and in some cases simply occupy) premises. Yet these inhabitants tend to keep a low profile lest their citizenship status be questioned. This does little to build community or establish any sense of place in the village. There is no way for rituals of everyday life to be established given this impermanence as the physical and social space degrades. The planned public spaces, namely the community hall and the open field, turned helipad, are completely devoid of people, limiting any possibility of building place through social interaction or shared use of common areas in the village. The one semi-public space, the 'bar' fashioned in the front yard of a homestay house, is visited overwhelmingly by NGO workers based in the village; a population that risks outnumbering permanent residents as the village's population continues to decline. Despite no regular inspections of the village, there is a sense that residents did not want to do the wrong thing and get into trouble from the donors or officials from the government by altering their dwellings too much. Furthermore there are limits on the degree to which the village can be altered given the permanency of the materials used and the layout. However resistance takes place in the small ways mentioned above; a boat in a yard, a thatched door, a chicken coop. Yet there is also a sense from residents that even the donors have lost interest and are not likely to return.

\section{Conclusion}

Following the 2004 Asian Tsunami donors the world over sought to 'build back better'. Baan Lion is a testament to the generosity of donors in attempting to rebuild lives. Yet as shown above, in this case they have largely failed to achieve their aims of rebuilding communities and restoring lives or livelihoods. We have argued that failure comes not from wrong intentions but from spatial dysfunction. Prior to the construction of the village there appears to have been a significant failure to consult with Moken people who were from the island of Koh Phra Thong - the main intended resident group at Baan Lion. There also seems to have been a failure by the Lions Club, the local government and other agencies (e.g. the SDC, the Department of Education) to sufficiently coordinate their post-tsunami projects on the island. At the core of the spatial dysfunction are clashing notions of usable/liveable and culturally appropriate space between donors and the intended inhabitants of the village. Dysfunction is most evident in the house design, planning/layout, location and usefulness of the village. Even when measures have been taken to accommodate the everyday lives of the Moken community, such as the building of the nearby pier, knowledge of these everyday lives is partial and outdated. This is unsurprising given the proliferation of literature by scholars and advocates written prior to, and especially following, the tsunami, that stresses the fragility of Moken traditions and their vulnerability, with little discussion of their capabilities and agency, nor any recognition of the ways Moken have adapted to the often dramatic ruptures in their lives. The irony here is that Moken are denied any representation as modern subjects by their supporters, yet at the same time are provided with a village of predetermined cheap housing, with a few minor concessions to local tastes or needs. Spatial dysfunction makes the possibilities of place-making remote. The planning of the village exacerbates this, with remaining residents separated by rows of empty houses with no functional public space in a suitable local form. Without access to social and economic networks, the intended inhabitants of the 
village have abandoned their new houses or never taken them up in the first place. This is different to the overt resistance to resettlement discussed by Anthony Oliver-Smith (1991b) wherein poorly planned resettlement acts as a process of political socialisation and contestation of authority. In this case, Moken act by moving elsewhere, leasing their houses to others, or modifying their dwellings. This recalls the kinds of subtle resistance made famous by James Scott's concept of 'hidden transcripts' (1990). While intended inhabitants seek place elsewhere, a few other Thai and Moken residents have moved in, and some locals have been able to capitalise by renting out a handful of their houses to foreign NGO volunteers. Although local NGOs have tried their best to introduce a number of new elements of community and place to attract tourists, there is still a palpable sense of transience and emptiness in Baan Lion.

\section{Acknowledgment}

Thank you to the National Research Council of Thailand for Granting Permission for this project (0002/9414).

\section{Appendix A. Supplementary material}

Supplementary data associated with this article can be found, in the online version, at http://dx.doi.org/10.1016/j.geoforum.2013. 04.023. These data include Google maps of the most important areas described in this article.

\section{References}

Agnew, J., 2011. Space and place. In: Agnew, J., Livingstone, D. (Eds.), The Sage Handbook of Geographical Knowledge. Sage, London, pp. 316-330.

Arunotai, N. 2002. Moken Livelihoods in the Surin Islands National Park. Paper Presented in the Workshop on Wise Coastal Practice for Asia and the Pacific Organized by the Environment and Development in Coastal Regions and Small Islands (CSI), UNESCO, at Khuraburi Greenview Resort, Khuraburi District, Phang-nga Province, November 25-28.

Arunotai, N., 2006. Moken traditional knowledge: an unrecognized form of natural resources management and conservation. International Social Science Journa $187,139-150$.

Arunotai, N., 2007. Mobility and Human Security seen from the Case if the Moken Sea Nomad in Thailand. Paper Presented at 3rd Congress of Reseau Asie, 26-28 September 2007, Paris, France. <http://www.reseau-asie.com/cgi-bin/prog/ pform.cgi?langue $=$ fr\&Mcenter $=$ colloque $\&$ TypeListe=showdoc\&ID_document $=$ 449>.

Arunotai, N., 2008. Saved by an old legend and a keen observation: the case of Moken sea nomads in Thailand. In: Shaw, R., Uy, N., Baumwoll, J. (Eds.), Indigenous Knowledge for Disaster Risk Reduction: Good Practice and Lessons Learned from Experiences in the Asia-Pacific Region. UNISDR, Bangkok, pp. 73 78.

Assavanonda, A., 2005. Shoddy Housing Doesn't Make a Home. Bangkok Post, December 2005. <http://www.bangkokpost.com/tsunami1yearon/07_shoddy. html $>$ (accessed 25.03.13).

Barakat, S., Zyck, S.A., 2011. Housing reconstruction as socio-economic recovery and state building: evidence from Southern Lebanon. Housing Studies 26, 133-154.

Bosher, L., 2011. Household and governmental perceptions of risk: implications for the appropriateness of housing provision in South India. Housing Studies 26, 241-257.

Chang, Y., Wilkinson, S., Potangaroa, R., Seville, E., 2011. Donor-driven resource procurement for post-disaster reconstruction: constraints and actions. Habitat International 35, 199-205.

Chou, C., 2006. Research trends on Southeast Asian Sea Nomads. Kyoto Review of Southeast Asia 7, 1-12.

Dancause, K., Chan, C., Arunotai, N., Lum, J., 2009. Origins of the Moken Sea Gypsies inferred from mitochondrial hypervariable region and whole genome sequences. Journal of Human Genetics 54, 86-93.

Davidson, C.H., Johnson, C., Lizarralde, G., Dikmen, N., Sliwinski, A., 2007. Truths and myths about community participation in post-disaster housing projects. Habitat International 31, 100-115.
Ferrari, O., Ivanoff, J., 2010. Does Globalisation Act as an Ethnocide? Reseau Asie. <http://www.reseau-asie.com/edito-en/globalisation-ethnocide-ferrariivanoff/> (01.09.10)

Ferrari, O., Hinshiranan, N., Utpuay, K., Ivanoff, J., 2006. Turbulence on Koh Phra Thong. Coll Kétos Anthropologie Maritime, Paris.

Friedmann, J., 2007. Reflections on place and place-making in the cities of China. International Journal of Urban and Regional Research 31, 257-279.

Ganapati, N.E., Ganapati, S., 2008. Enabling participatory planning after disasters: a case study of the World Bank's housing reconstruction in Turkey. Journal of the American Planning Association 75, 41-59.

Gravers, M., 2007. Introduction: ethnicity against state-state against ethnic diversity? In: Gravers, M. (Ed.), Ethnic Diversity in Burma. NIAS, Copenhagen, pp. 1-33.

Hilhorst, D., Christoplos, I., Van Der Harr, G., 2010. Reconstruction 'From Below': a new magic bullet or shooting from the hip? Third World Quarterly 31, 11071124.

Hogan, D., 1972. Men of the sea: coastal tribes of South Thailand's West coast. Journal of the Siam Society 60, 205-235.

Hyndman, J., 2007. The securitisation of fear in post-tsunami Sri Lanka. Annals of the Association of American Geographers 97, 361-372.

IUCN, 2006. Guide to Koh Phra Thong Natural Habitats. IUCN, Bangkok.

Ivanoff, J., 1997. Moken, Sea-Gypsies of the Andaman Sea, White Lotus, Bangkok.

Ivanoff, J., Lejard, T., 2002. A Journey through the Mergui Archipelago, White Lotus, Bangkok.

Kennedy, J., Ashmore, J., Babister, E., Kelman, I., 2008. The meaning of 'build back better: evidence from post-tsunami Aceh and Sri Lanka. Journal of Contingencies and Crisis Management 16, 24-36.

Kritsanarangsan, S., Scheuer, H., 2008. External Review of SDC's Post-Tsunami Relief and Rehabilitation Assistance for Fishing Communities of Ko Phra Thong and Ko Kho Khao, Kura Buri District, Thailand. SDC and FDFA, Switzerland.

Lauer, M., 2012. Oral traditions or situated practices? Understanding how indigenous communities respond to environmental disasters. Human Organization 71, 176-187.

LCIF, 2009. Lions Club International Foundation: Annual Report 2008-2009. <http:// www.lcif.org/EN/_files/pdfs/lcif30_08-09.pdf>.

Lebel, L., Khrutmuang, S., Manuta, J., 2006. Tales from the margins: small fishers in post-tsunami Thailand. Disaster Prevention and Management 15, 124-134.

Lefebvre, H., 1991. The Production of Space. Blackwell, Oxford.

Massey, D., 1993. Power-geometry and a progressive sense of place. In: Bird, J., Curtis, B., Putnam, T., Tickner, L. (Eds.), Mapping the Futures: Local Cultures, Global Change. Routledge, London, pp. 60-70.

Mercer, J., Dominey-Howes, D., Kelman, I., Lloyd, K., 2007. The potential for combining indigenous and western knowledge in reducing vulnerability to environmental hazards in small islands developing states. Environmental Hazards 7, 245-256.

Merrifield, A., 1993. Place and space: a Lefebvrian reconciliation. Transactions of the Institute of British Geographers 18, 516-531.

Nidhiprabha, B., 2007. Adjustment and Recovery in Thailand Two Years after the Tsunami, Asian Development Bank Institute Discussion Papers, No. 72, ADB, Tokyo. <http://hdl.handle.net/10419/53440>.

Oliver-Smith, A., 1991a. Successes and failures in post-disaster resettlement. Disasters 15, 12-23.

Oliver-Smith, A., 1991b. Involuntary resettlement, resistance and political empowerment. Journal of Refugee Studies 4, 132-149.

Oliver-Smith, A., 2007. Post-disaster housing reconstruction and social inequality: a challenge to policy and practice. Disasters 14, 7-19.

Rungmanee, S., Cruz, I., 2005. The knowledge that saved the sea gypsies. World of Science 3, 20-23.

Scott, J.C., 1990. Hidden Transcripts: Domination and the Arts of Resistance. Yale University Press, New Haven.

Sopher, D., 1977. The Sea Nomads: A Study of the Maritime Boat People of Southeast Asia. National Museum Publications, Singapore.

Sorenson, R., 1997. The Moken of Mergui: the study of child behaviour and human development in cultural isolates. Anthropology of Consciousness 8, 168-172.

Steckley, M., Doberstein, B., 2011. Tsunami survivors' perspectives on vulnerability and vulnerability reduction: evidence from Koh Phi Phi Don and Khao Lak, Thailand. Disasters 35, 465-487.

UNESCO, 2007. Bridging the Gap Between the Rights and Needs of Indigenous Communities and the Management of Protected Areas: Case Studies from Thailand. UNESCO, Bangkok.

UNESCO, 2005. Spared by the Sea, The New Courier, May 53-55.

UNESCO, 2001. Indigenous Peoples and Parks: The Surin Islands Project. UNESCO, Bangkok.

Williams, S., Jacobs, K., 2011. Introduction: disasters, housing, actuarialism and the securitisation of risk. Housing Studies 26, 185-195.

Wong, P., 2009. Rethinking post-tsunami integrated coastal management for AsiaPacific. Ocean and Coastal Management 52, 405-410. 